DOI: $10.15593 / 2224-9982 / 2018.52 .08$

УДК 62-97

\author{
О.О. Матюнин, А.А. Шилова, Н.Л. Бачев, Р.В. Бульбович
}

Пермский национальный исследовательский политехнический университет, Пермь, Россия

\author{
АНАЛИЗ ГЕОМЕТРИЧЕСКИХ И ТЕПЛОВЫХ ХАРАКТЕРИСТИК \\ ВЫСОКОРЕСУРСНОЙ УТИЛИЗАЦИОННОЙ КАМЕРЫ СГОРАНИЯ
}

\begin{abstract}
При создании отечественной газотурбинной установки (ГТУ) блочно-модульного типа для утилизации нефтяного газа (НГ) на малодебитных месторождениях требуется разработка специальной универсальной камеры сгорания (КС), которая обеспечивала бы устойчивое горение сильно забалластированных нефтяных газов разного состава на разных месторождениях. Для организации низкоэмиссионного горения предложена трехзонная КС с организацией богатобедного горения. КС является подсистемой отечественной судовой ГТУ типа ТК-23, поэтому распределение давления, температуры, коэффициента избытка и расхода воздуха согласованы с параметрами отечественного турбокомпрессора. Геометрические параметры КС определены с использованием обобщенных характеристик рабочего процесса (время пребывания, относительная и объемная расходонапряженность). Для увеличения ресурса работы энергоустановки предложена наружная противоточная система охлаждения с использованием продольно-оребренной рубашки. В качестве охладителя используется окислитель (воздух), подаваемый в рубашку охлаждения турбокомпрессором типа ТК-23. Осуществляя теплосъем с огневой стенки, воздух нагревается и в подогретом состоянии подается в зоны разбавления, дожигания и горения, увеличивая тем самым стабильность горения сильнозабалластированных нефтяных газов. Тепловые характеристики огневой стенки и охладителя в рубашке охлаждения получены из решения уравнений теплового баланса для каждого участка, на которые была разбита КС в продольном направлении. Исследования показали сильное влияние коэффрициента оребрения рубашки охлаждения на тепловое состояние огневой стенки.

Ключевые слова: утилизация нефтяного газа, высокоресурсная камера сгорания, наружное противоточное охлаждение, богато-бедное горение, геометрические и тепловые характеристики.
\end{abstract}

\author{
O.O. Matyunin, A.A. Shilova, N.L. Bachev, R.V. Bulbovich
}

Perm National Research Polytechnic University, Perm, Russian Federation

\title{
ANALYSIS OF GEOMETRIC AND THERMAL CHARACTERISTICS OF A HIGH-RESOURCE COMBUSTION CHAMBER
}

\begin{abstract}
When creating a domestic gas turbine unit of the block-modular type for the utilization of petroleum gas at low-yield fields, the development of a special universal combustion chamber, which would ensure the sustained combustion of highly ballasted oil gases of different composition in different fields, is required. For the organization of low emission combustion, a threezone combustion chamber with an organization of rich-poor combustion is proposed. The combustion chamber is a subsystem of the domestic ship gas turbine plant of the TK-23 type, so the distribution of pressure, temperature, excess ratio and air flow are coordinated with the parameters of the domestic turbocharger. Geometrical parameters of the combustion chamber are determined using generalized characteristics of the working process (residence time, relative and volumetric flow). To increase the life of the power plant, an outdoor countercurrent cooling system using a longitudinally-ribbed shirt is proposed. As the coolant, an oxidizer (air) is used, fed into the cooling jacket by a TK-23 turbocharger. Carrying out heat from the fire wall, the air heats up and, in a warmed state, is supplied to the dilution, afterburning and combustion zones, thereby increasing the stability of combustion of highly ballasted oil gases. The thermal characteristics of the fire wall and the cooler in the cooling jacket are obtained from the solution of the heat balance equations for each section into which the combustion chamber was divided in the longitudinal direction. Studies have shown a strong effect of the cooling fin finning coefficient on the thermal state of the fire wall.

Keywords: utilization of petroleum gas, high-resource combustion chamber, external countercurrent cooling, rich-poor combustion, geometric and thermal characteristics.
\end{abstract}

\section{Введение}

На сегодняшний день остро стоит вопрос об утилизации НГ на малодебитных месторождениях. Опыт использования импортных ГТУ типа Capstone показал, что необходима разработка специальной КС для утилизации сложных по составу, сильно забалластированных и серосодержащих НГ [1-3]. В настоящее время разрабатывается отечественная утилизационная ГТУ 
блочно-модульного типа с использованием судового турбокомпрессора типа ТК-23, в состав которой в качестве подсистемы входит КС с тепловой мощностью 1 МВт. Для снижения концентрации вредных и токсичных веществ в составе выхлопных газов предложена трехзонная КС с организацией богато-бедного горения [4]. Наружное противоточное охлаждение огневой стенки является одним из факторов повышения ресурса работы утилизационной энергоустановки. В качестве охладителя используется воздух, подаваемый в продольно-оребренную рубашку охлаждения судовым турбокомпрессором типа ТК-23.

\section{Анализ геометрических характеристик утилизационной КС}

Принципиальная схема утилизационной трехзонной КС представлена на рис. 1. Зона горения (зона № 1) отвечает за устойчивое горение забалластированных НГ разного состава. Рабочий процесс в зоне № 1 протекает при $\alpha_{1}=0,8$, который является универсальным и выбран из диапазона устойчивого горения НГ для разных месторождений [5-6]. В зоне дожигания (зона № 2) происходит переход от режима богатого горения к режиму бедного горения при $\alpha_{2}=2,0$ [7]. Зона разбавления (зона № 3) отвечает за создание необходимых параметров рабочего тела турбины. По данным термодинамического расчета в зоне № 3 выбрано значение $\alpha_{3}=5,0$, что соответствует температуре рабочего тела на входе в турбину $T_{\mathrm{Bx}}^{\mathrm{T}}=973 \mathrm{~K}$ [8] в соответствии с требованиями турбокомпрессора типа ТК-23.

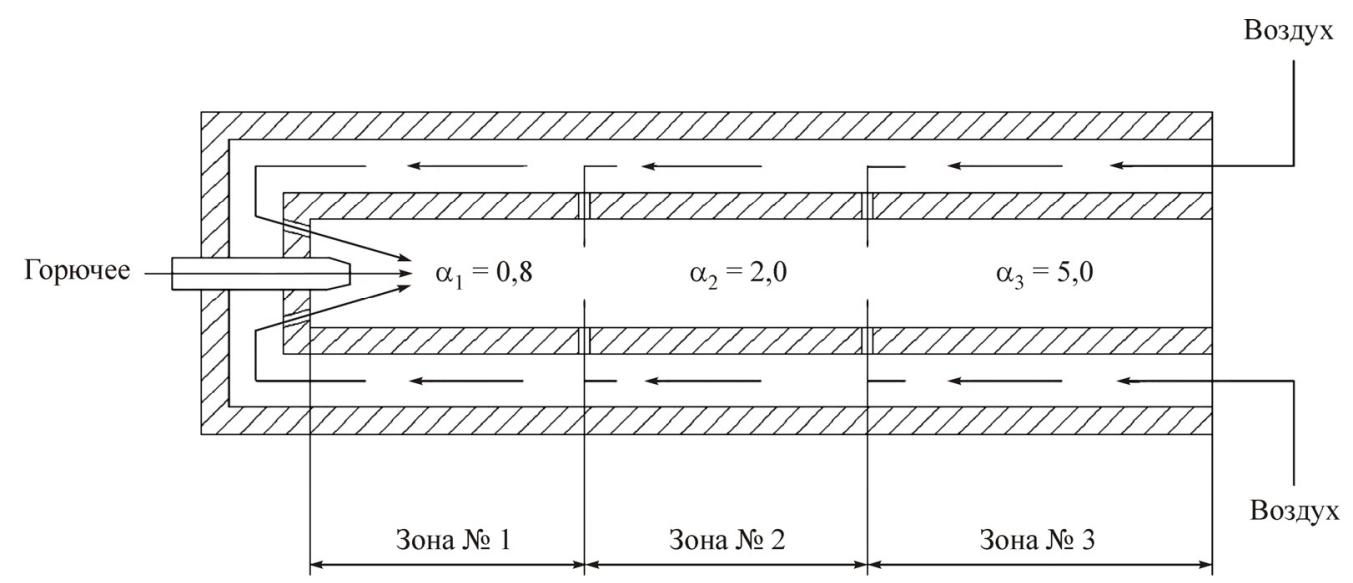

Рис. 1. Принципиальная схема утилизационной КС

Воздух после компрессора движется по продольно-оребренной рубашке охлаждения, отбирает тепло от огневой стенки и в подогретом состоянии через боковые отверстия поступает сначала в зону разбавления, затем в зону дожигания и через струйные форсунки в зону горения. Предварительный подогрев воздуха в рубашке повышает стабильность горения забалластированных разнородных НГ в зоне № 1.

Расход горючего (НГ) в зону горения

$$
G_{\text {гор }}=\frac{N}{H_{u}}
$$

где $N$ - тепловая мощность КС; $H_{u}$ - теплопроизводительность НГ.

Суммарный расход окислителя (воздуха) через КС

$$
G_{\text {ок }}=\alpha_{3} K_{m 0} G_{\text {гор }},
$$

где $\alpha_{3}$ - коэффициент избытка окислителя в зоне разбавления; $K_{m 0}-$ стехиометрическое соотношение компонентов. 
Распределение расходов окислителя (воздуха) по зонам осуществляется следующим образом:

$$
\begin{gathered}
G_{\text {ок } 1}=\alpha_{1} K_{m 0} G_{\text {г }}, \\
G_{\text {ок } 2}=\alpha_{2} K_{m 0} G_{\text {гор }}-G_{\text {ок } 1}, \\
G_{\text {ок } 3}=G_{\text {ок }}-G_{\text {ок } 1}-G_{\text {ок } 2},
\end{gathered}
$$

где $\alpha_{1}$ и $\alpha_{2}-$ коэффициенты избытка окислителя в зоне горения и в зоне дожигания соответственно.

Расходы ПС по зонам составляют

$$
\begin{aligned}
& G_{1}=G_{\text {ок } 1}+G_{\text {г }}, \\
& G_{2}=G_{1}+G_{\text {ок } 2,} \\
& G_{3}=G_{2}+G_{\text {ок } 3 .} .
\end{aligned}
$$

Диаметр КС определяется по заданной расходонапряженности $g_{\text {к }}$ :

$$
\begin{gathered}
F_{\mathrm{\kappa}}=\frac{G_{\mathrm{OK}}+G_{\mathrm{\Gamma}}}{g_{\mathrm{K}} P_{\mathrm{K}}}, \\
d_{\mathrm{\kappa}}=\sqrt{\frac{4 F_{\mathrm{K}}}{\pi}},
\end{gathered}
$$

где $P_{\text {к }}$ - давление в КС; $g_{\text {к }}=(0,7 \ldots 2,9) 10^{-4}$ кг/(c·H) $[9,10]$.

Длины зон определяются по времени пребывания газа $\tau_{i}$ в каждой зоне:

$$
l_{i}=\frac{4 G_{i} \tau_{i}}{\pi d_{\kappa}^{2} \rho_{i}}, i=1,2,3
$$

где $i$ - номер зоны; $\rho_{i}-$ плотность газа в $i$-й зоне; $\tau_{i}=1 \ldots 5$ мс $[9,10]$.

Диаметры струйных форсунок для подачи НГ и первичного воздуха в зону горения

$$
d_{\phi}=\sqrt{\frac{4 G_{\phi}}{\pi \mu_{\phi} \sqrt{2 \rho \Delta P_{\phi}}}},
$$

где $G_{\phi}$ - расход через форсунку; $\mu_{\phi}$ - коэффициент расхода форсунки; $\Delta P_{\phi}-$ перепад давления на форсунке.

Суммарная площадь боковых отверстий для подвода вторичного воздуха в зоны дожигания и разбавления $(i=2,3)$ [7]

$$
F_{i}=\frac{G_{\text {ок } i}}{\mu_{\text {отв }} \sqrt{2 \rho_{\text {ок }} \Delta P_{\text {ок }}}}
$$

где $\mu_{\text {отв }}$ - коэффициент расхода бокового отверстия; $\rho_{\text {ок }}-$ плотность окислителя; $\Delta P_{\text {ок }}-$ перепад давления на боковом отверстии.

Количество боковых отверстий для подвода вторичного воздуха

$$
n_{i}=\frac{4 F_{i}}{\pi d_{\text {отвi }}^{2}}
$$

где $d_{\text {отв }}-$ диаметр бокового отверстия. 
Шаг расположения боковых отверстий в $i$-й зоне

$$
t_{i}=\frac{\pi d_{\mathrm{K}}}{n_{i}}
$$

Важной характеристикой является глубина проникновения струи вторичного воздуха в поток газа. Для струи вторичного воздуха, втекающей через круглое боковое отверстие, глубину проникновения можно определить по эмпирической формуле [7, 11]

$$
H=d_{\text {отв } i}\left[0,3+0,45\left(\frac{W_{\text {ок }}}{W_{i}}\right)\right]\left(\frac{d_{\mathrm{\kappa}}}{2 d_{\text {отв }}}\right)^{0,63} .
$$

Скорость вторичного воздуха через боковое отверстие

$$
W_{\text {ок } i}=\frac{4 G_{\text {ок } i}}{n_{\text {отв }} \rho_{\text {ок }} \mu_{\text {отв }} \pi d_{\text {отв }}^{2}},
$$

где $n_{\text {отвi }}$ - количество боковых отверстий в $i$-й зоне.

Скорость потока газа в $i$-й зоне

$$
W_{i}=\frac{4 G_{i}}{\rho_{i} \pi d_{\text {отв }}^{2}} .
$$

Геометрические и режимные характеристики спроектированной утилизационной КС

\begin{tabular}{|c|c|c|c|}
\hline Параметры & Обозначение & Размерность & Величина \\
\hline Тепловая мощность & $N$ & МBт & 1,0 \\
\hline Давление воздуха на входе & $P_{\mathrm{BX}}$ & МПа & 0,35 \\
\hline Давление ПС на выходе & $P_{\text {вых }}$ & МПа & 0,34 \\
\hline Температура воздуха на входе в рубашку охлаждения & $T_{\mathrm{Bx}}^{\mathrm{or}}$ & К & 412 \\
\hline Массовый расход топливного газа в зоне горения & $G_{\text {гор }}$ & кг/с & 0,032 \\
\hline Суммарный массовый расход воздуха & $G_{\text {ок }}$ & кг/с & 1,683 \\
\hline Температура топливного газа на входе & $T_{\mathrm{Bx}}^{\mathrm{r}}$ & K & 288 \\
\hline Температура ПС на выходе & $T_{\text {вых }}^{\mathrm{r}}$ & K & 973 \\
\hline Длина & $L_{\Sigma}$ & м & 0,349 \\
\hline Внутренний диаметр & $d_{\mathrm{\kappa}}$ & м & 0,25 \\
\hline Стехиометрическое соотношение компонентов & $K_{m 0}$ & - & 10,6 \\
\hline \multicolumn{4}{|c|}{ Зона № 1 (зона горения) } \\
\hline Массовый расход воздуха & $G_{\text {ок } 1}$ & $\kappa г / \mathrm{c}$ & 0,269 \\
\hline Массовый расход топливного газа & $G_{\text {rор }}$ & кг/с & 0,032 \\
\hline Массовый расход ПС & $G_{1}$ & кг/c & 0,301 \\
\hline Коэффициент избытка воздуха & $\alpha_{1}$ & - & 0,8 \\
\hline Температура ПС & $T_{1}$ & К & 2260 \\
\hline
\end{tabular}
приведены в табл. 1.

Таблица 1

Геометрические и режимные параметры утилизационной КС 
Продолжение табл. 1

\begin{tabular}{|c|c|c|c|}
\hline Параметры & Обозначение & Размерность & Величина \\
\hline Скорость ПС на выходе из зоны & $W_{1}$ & $\mathrm{M} / \mathrm{c}$ & 12,6 \\
\hline Длина зоны & $L_{1}$ & M & 0,063 \\
\hline Время пребывания & $\tau_{1}$ & Mc & 5 \\
\hline Количество форсунок горючего & $n_{\text {гор }}$ & - & 1 \\
\hline Диаметр форсунки горючего & $d_{\text {rop }}$ & MM & 9 \\
\hline Количество форсунок окислителя & $n_{\text {ок }}$ & - & 6 \\
\hline Диаметр форсунки окислителя & $d_{\mathrm{O \kappa}}$ & MM & 8 \\
\hline \multicolumn{4}{|c|}{ Зона № 2 (зона дожигания) } \\
\hline Массовый расход воздуха & $G_{\text {ок2 }}$ & кг/с & 0,404 \\
\hline Массовый расход топливного газа & $G_{\text {гор }}$ & кг/c & - \\
\hline Массовый расход ПС & $G_{2}$ & кг/с & 0,708 \\
\hline Коэффициент избытка воздуха & $\alpha_{2}$ & - & 2,0 \\
\hline Температура ПС & $T_{2}$ & $\mathrm{~K}$ & 1690 \\
\hline Скорость ПС на выходе из зоны & $W_{2}$ & $\mathrm{M} / \mathrm{c}$ & 20,8 \\
\hline Длина зоны & $L_{2}$ & M & 0,404 \\
\hline Время пребывания & $\tau_{2}$ & Mc & 5 \\
\hline Потребная площадь боковых отверстий & $F_{12}$ & M & $5,016 \cdot 10^{-4}$ \\
\hline Количество отверстий & $n_{\text {отв }}$ & - & 70 \\
\hline Диаметр отверстий & $d_{\text {отв }}$ & MM & 3 \\
\hline Шаг расположения отверстий & $t$ & MM & 11 \\
\hline \multicolumn{4}{|c|}{ Зона № 3 (зона разбавления) } \\
\hline Массовый расход воздуха & $G_{\text {ок3 }}$ & кг/c & 1,010 \\
\hline Массовый расход топливного газа & $G_{\text {гор }}$ & кг/с & - \\
\hline Массовый расход ПС & $G_{3}$ & кг/с & 1,714 \\
\hline Коэффициент избытка воздуха & $\alpha_{3}$ & - & 5,0 \\
\hline Температура ПС & $T_{3}$ & K & 973 \\
\hline Скорость ПС на выходе из зоны & $W_{3}$ & $\mathrm{M} / \mathrm{c}$ & 36,42 \\
\hline Длина зоны & $L_{3}$ & M & 0,182 \\
\hline Время пребывания & $\tau_{3}$ & Mc & 5 \\
\hline Потребная площадь боковых отверстий & $F_{23}$ & M & $1,254 \cdot 10^{-4}$ \\
\hline Количество отверстий & $n_{\text {отв }}$ & - & 63 \\
\hline Диаметр отверстий & $d_{\text {отв }}$ & MM & 5 \\
\hline Шаг расположения отверстий & $t$ & MM & 12 \\
\hline
\end{tabular}




\section{Анализ тепловых характеристик утилизационной КС}

Одной из важнейших характеристик, определяющих надежность и ресурс утилизационной КС, является температура огневой стенки. Определение температуры конструкционных элементов КС следует после определения режимных и геометрических параметров. При оценке температурного режима огневой стенки конструктора в первую очередь интересует максимальная температура. Местоположение и значение этой температуры определяется характером распределения тепловых потоков по длине КС [12].

Локальное значение температуры огневой стенки может быть найдено решением уравнения теплового баланса, составленного для произвольного участка огневой стенки в установившемся режиме работы [13]

$$
\left(q_{\mathrm{K}}\right)_{\mathrm{\Gamma}-\mathrm{CT}}+\left(q_{\mathrm{K}}\right)_{\text {Г-ст }}=\left(q_{\mathrm{K}}\right)_{\text {ст-охл }} .
$$

Конвективный тепловой поток от ПС в огневую стенку [14]

$$
\left(q_{\mathrm{K}}\right)_{\text {г-ст }}=\alpha_{\text {г-ст }}\left(T_{\text {г }}-T_{\text {ст.г }}\right),
$$

где $T_{\text {г }}, T_{\text {ст.г }}$ - температуры ПС и огневой стенки со стороны газа; $\alpha_{\text {г-ст }}-$ коэффициент теплообмена между газом и огневой стенкой.

Лучистый тепловой поток от ПС в огневую стенку [15]

$$
\left(q_{\text {л }}\right)_{\text {г-ст }}=\sigma \varepsilon_{\text {ст }} \varepsilon_{\text {г }}\left(T_{\text {г }}^{4}-T_{\text {ст.г }}^{4}\right),
$$

где $\sigma$ - постоянная Стефана-Больцмана; $\varepsilon_{\text {cт }}, \varepsilon_{\text {г }}$ - степени черноты огневой стенки и газа соответственно.

Конвективный тепловой поток от огневой стенки в охладитель

$$
\left(q_{\mathrm{K}}\right)_{\text {ст-охл }}=\alpha_{\text {ст-охл }} \cdot \varphi\left(T_{\text {ст-охл }}-T_{\text {охл }}\right),
$$

где $T_{\text {охл }}$ и $T_{\text {ст-охл }}-$ температуры охладителя и огневой стенки со стороны охладителя; $\alpha_{\text {ст-охл }}-$ коэффициент теплообмена между огневой стенкой и охладителем; $\varphi$ - коэффициент оребрения охлаждающего тракта.

Уравнение переноса тепла через огневую стенку

$$
\left(q_{\mathrm{K}}\right)_{\text {г }- \text { ст }}+\left(q_{\text {л }}\right)_{\text {г-ст }}=\frac{\lambda_{\text {ст }}}{\delta_{\text {ст }}}\left(T_{\text {ст-г }}-T_{\text {ст-охл }}\right),
$$

где $\lambda_{\text {ст }}$ и $\delta_{\text {ст }}-$ коэффициент теплопроводности и толщина стенки.

Скорость охладителя в рубашке охлаждения

$$
W_{\text {охлі }}=\frac{G_{\text {охлі }}}{\rho_{\text {охллі }} F_{\text {охл }}},
$$

где $F_{\text {охл }}$ - площадь живого сечения.

Расходы охладителя в рубашке охлаждения для каждой зоны

$$
\begin{gathered}
G_{\text {охл } 3}=G_{\text {ок }}, \\
G_{\text {охл2 }}=G_{\text {охл3 }}-G_{\text {ок } 3}, \\
G_{\text {охл1 }}=G_{\text {охл2 }}-G_{\text {ок } 2} .
\end{gathered}
$$

При расчете теплового состояния охладителя учитывались следующие зависимости теплофизических характеристик от температуры [14]: 


$$
\begin{gathered}
\mu=1,717 \cdot 10^{-5}\left(\frac{T_{\text {охл }}}{273}\right)^{0,683}, \\
\lambda=2,44 \cdot 10^{-2}\left(\frac{T_{\text {охл }}}{273}\right)^{0,82}, \\
c_{p}\left[1,0005+1,1904 \cdot 10^{-4}(T-273)\right] .
\end{gathered}
$$

Пояснения и последовательность определения величин, входящих в формулы (1)-(7), приведены в [4].

Геометрические параметры продольно-оребренной рубашки охлаждения представлены в табл. 2.

\begin{tabular}{|c|c|c|c|}
\hline Параметры & Обозначение & Размерность & Величина \\
\hline Толщина огневой стенки & $\delta_{\mathrm{cT}}$ & MM & 4 \\
\hline Внутренний диаметр рубашки охлаждения & $d_{\text {охл }}$ & MM & 260 \\
\hline Толщина ребра & $\delta_{\mathrm{p}}$ & MM & 4 \\
\hline Высота рубашки охлаждения & $h_{\text {охл }}$ & MM & 7 \\
\hline Высота ребра & $h_{\mathrm{p}}$ & MM & 5 \\
\hline Шаг & $t$ & MM & 20 \\
\hline Количество ребер & $n_{\mathrm{p}}$ & - & 40 \\
\hline Наружный диаметр рубашки охлаждения & $D_{\text {охл }}$ & MM & 272 \\
\hline Коэффициент оребрения & $\varphi$ & - & 1,5 \\
\hline $\begin{array}{l}\text { Коэффициент теплопроводности материала } \\
\text { огневой стенки }\end{array}$ & $\lambda_{\mathrm{cT}}$ & $\mathrm{BT} /(\mathrm{M} \cdot \mathrm{K})$ & 25 \\
\hline Количество участков теплообмена в зоне № 1 & $m_{1}$ & - & 9 \\
\hline Количество участков теплообмена в зоне № 2 & $m_{2}$ & - & 10 \\
\hline Количество участков теплообмена в зоне № 3 & $m_{3}$ & - & 14 \\
\hline
\end{tabular}

Таблица 2

Геометрические параметры продольно-оребренной рубашки охлаждения

Приведенные ниже результаты теплового расчета получены при коэффициенте оребрения $\varphi=1,5$.

На рис. 2 показаны скорости газов и охладителя вдоль КС.

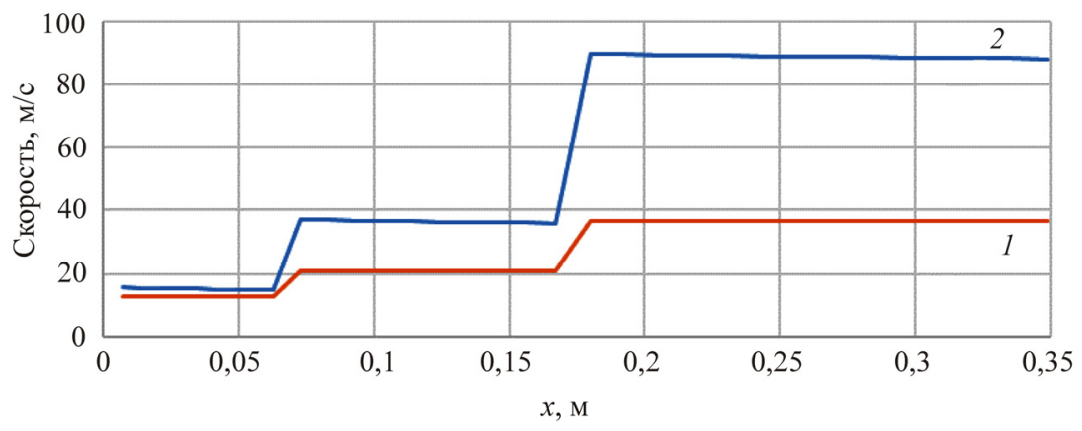

Рис. 2. Скорости газа и охладителя вдоль КС: 1 - скорость газа;

2 - скорость охладителя 
Профили скорости вдоль КС имеют ступенчатый характер изменения, так как воздух из рубашки охлаждения в соответствующие зоны подается дискретно. Уменьшение скорости охладителя по направлению к форсуночной головке $(x=0)$ объясняется тем, что при противоточном движении в рубашке часть охладителя подается внутрь соответствующих зон КС. Этим же фактором объясняется увеличение скорости ПС по направлению к выходному сечению из КС.

На рис. 3 представлены коэффициенты теплообмена между ПС и огневой стенкой $\alpha_{\text {г-ст }}$ и огневой стенкой и охладителем $\alpha_{\text {ст-охл }}$ вдоль КС.

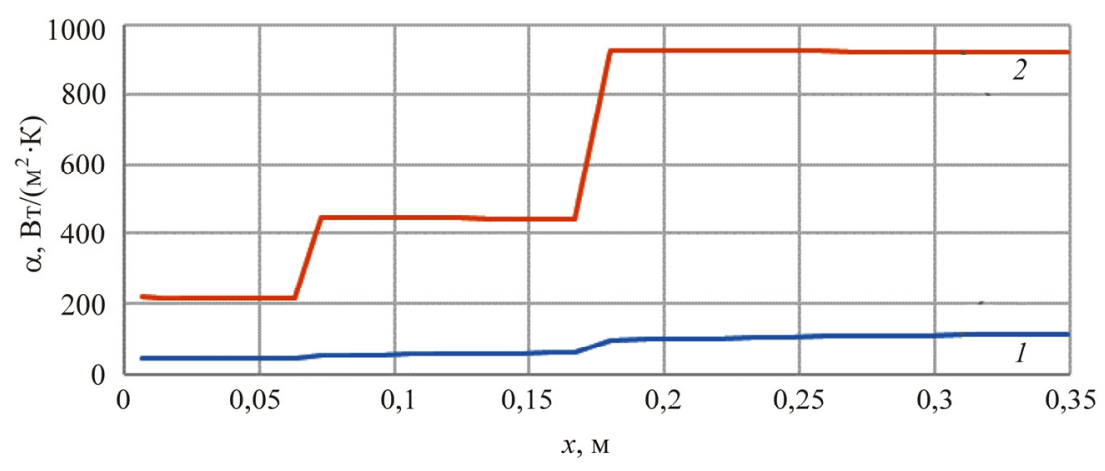

Рис. 3. Коэффициенты теплообмена вдоль КС: $1-\alpha_{\text {г-ст }} ; 2-\alpha_{\text {ст-охл }}$

Сильная зависимость теплофизических свойств ПС от температуры приводит к сглаживанию значений $\alpha_{\text {г-ст }}$ вдоль КС. Коэффициент теплообмена между огневой стенкой и охладителем $\alpha_{\text {ст-охл }}$ вдоль КС определяется в основном профилем скорости охладителя вдоль КС.

На рис. 4 представлены конвективные, лучистые и суммарные тепловые потоки от ПС в огневую стенку.

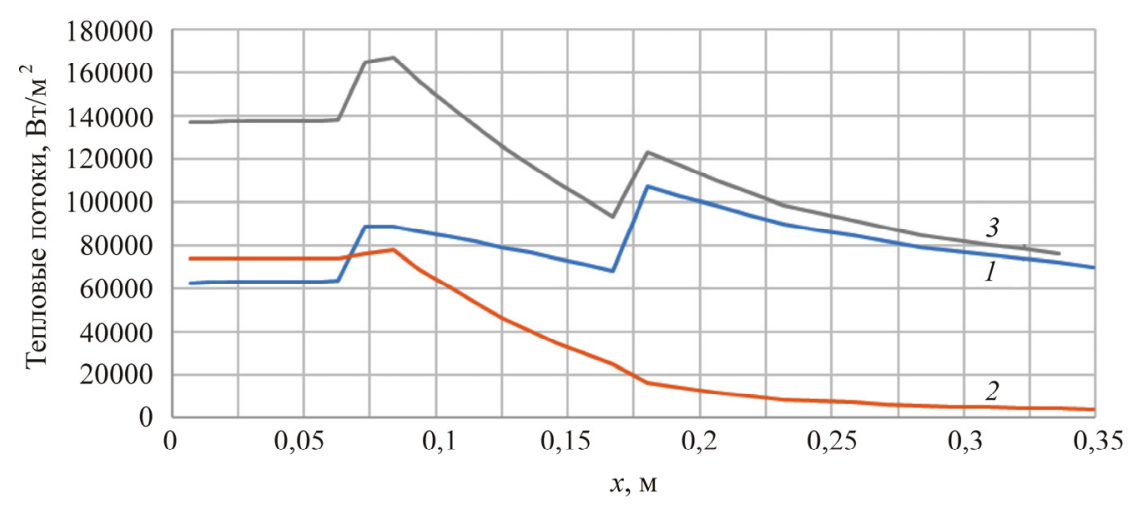

Рис. 4. Тепловые потоки вдоль КС: 1 - конвективный тепловой поток; 2 - лучистый тепловой поток; 3 - суммарный тепловой поток

В зоне богатого горения и в области перехода через стехиометрическое соотношение лучистые тепловые потоки превосходят конвективные. В зонах дожигания и разбавления конвективные тепловые потоки, наоборот, превосходят лучистые. Максимальные значения суммарных тепловых потоков наблюдаются в области перехода от богатого горения к бедному.

На рис. 5 показаны температуры ПС, огневой стенки и охладителя вдоль КС.

Максимальное значение температуры ПС (2340 К) наблюдается в области перехода от богатого горения к бедному. В зонах дожигания и разбавления температура ПС уменьшается вследствие подвода вторичного воздуха - охладителя из рубашки охлаждения. Температура ПС вдоль зоны горения (зона № 1) принята постоянной (2260 К) и соответствует термодинамиче- 
скому значению при $\alpha_{1}=0,8$. В действительности в области форсуночной головки температура ПС будет ниже принятой, что приведет к менее теплонагруженному состоянию огневой стенки. Максимальная температура огневой стенки (898 К) ниже рабочей температуры хромоникелевых сталей (1100-1200 К), что свидетельствует об эффективности предложенной схемы охлаждения.

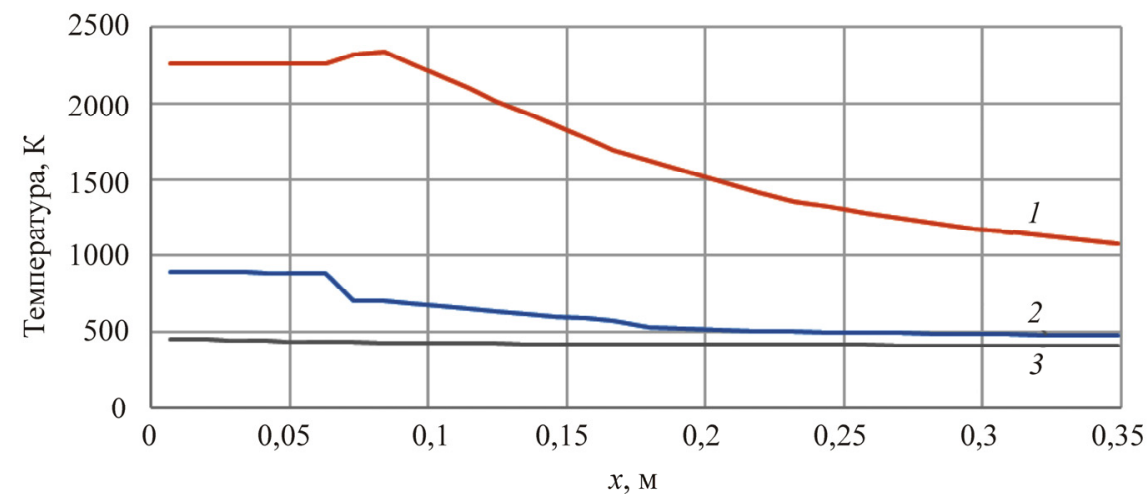

Рис. 5. Температуры вдоль КС: 1 - температура ПС; 2 - температура огневой стенки; 3 - температура воздуха

На рис. 6 приведены температуры огневой стенки для гладкого щелевого и продольнооребренного каналов.

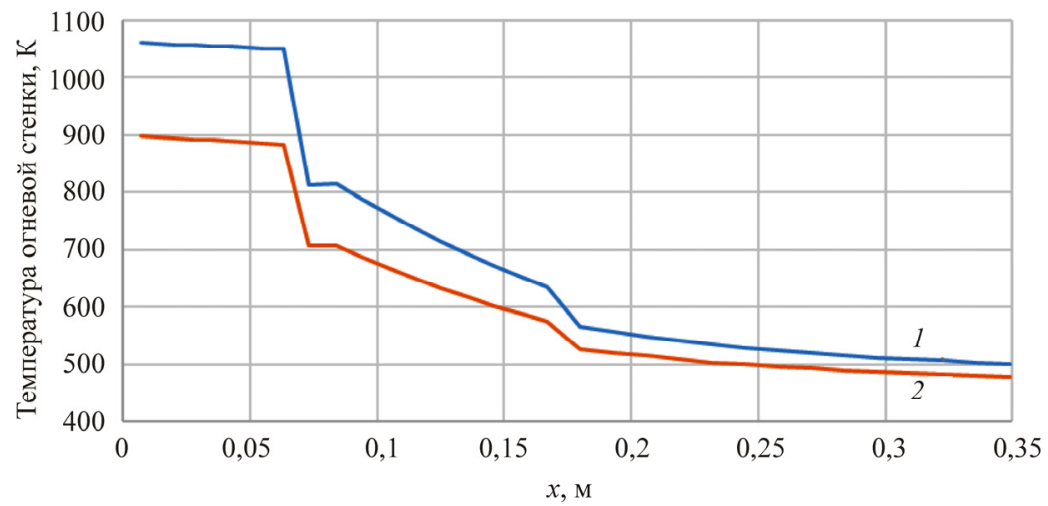

Рис. 6. Температуры огневой стенки для гладкого щелевого и продольно-оребренного каналов: $1-\varphi=1 ; 2-\varphi=1,5$

Анализ данных на рис. 6 показывает, что максимальная температура огневой стенки в случае применения оребрения с $\varphi=1,5$ снижается на $15 \%$ по сравнению с гладким щелевым каналом.

Таким образом, получены и проанализированы геометрические и тепловые характеристики утилизационной КС тепловой мощностью 1 МВт. Спроектированная КС предназначена для работы в составе ГТУ блочно-модульного типа с готовым судовым турбокомпрессором типа ТК-23. Предложенная противоточная система наружного охлаждения является эффективной и способствует увеличению ресурса работы утилизационной установки.

Статья публикуется при поддержке гранта РФФИ № 16-48-590072 «Разработка энергоустановки для утилизации нефтяных газов на малодебитных месторождениях с выработкой электрической энергии». 


\section{Библиографической список}

1. Бетинская О.А. Организация рабочего процесса в универсальной камере сгорания газотурбинной установки для утилизации попутного нефтяного газа: дис. ... канд. техн. наук: 05.04.12. - Пермь, 2017. - 146 c.

2. Выбор геометрических, режимных и тепловых параметров высокоресурсной камеры сгорания для утилизации ПНГ / О.А. Зуева, Н.Л. Бачев, Р.В. Бульбович, А.М. Клещевников // Газовая промышленность. - 2013. - № 698. - С. 94-97.

3. Выбор геометрических, режимных и тепловых параметров высокоресурсной камеры сгорания для утилизации попутного нефтяного газа / О.А. Зуева, Н.Л. Бачев, Р.В. Бульбович, А.М. Клещевников // Вестник Пермского национального исследовательского политехнического университета. Аэрокосмическая техника. - 2013. - № 34. - С. 40-51.

4. Анализ параметров наружного противоточного охлаждения камеры сгорания в составе утилизационной энергоустановки / А.А. Шилова (А.А. Селиванова), Н.Л. Бачев, Р.В. Бульбович, О.О. Матюнин // Вестник Пермского национального исследовательского политехнического университета. Аэрокосмическая техника. - 2017. - № 50. - С. 80-89.

5. Зуева О.А. Концентрационные пределы горения попутных нефтяных газов // Вестник Пермского национального исследовательского политехнического университета. Аэрокосмическая техника. 2014. - № 37. - С. 140-153.

6. Бетинская О.А. (Зуева О.А.). Пределы устойчивого горения нефтяных газов // Нефтяное хозяйство. - 2014. - Вып. 1089. - С. 64-66.

7. Иноземцев А.А., Нихамкин М.А., Сандрацкий В.Л. Основы конструирования авиационных двигателей и энергетических установок: учебник. - М.: Машиностроение, 2008. - Т. 2. - 368 с. (Серия: Газотурбинные двигатели).

8. Использование антикоррозионных присадок при сжигании серосодержащих углеводородных топлив / О.О. Матюнин, Н.Л. Бачев, Р.В. Бульбович, Н.Ю. Бачева // Вестник Пермского национального исследовательского политехнического университета. Аэрокосмическая техника. - 2017. - № 49. - С. $78-88$.

9. Добровольский М.В. Жидкостные ракетные двигатели. - М.: Изд-во МГТУ им. Н.Э. Баумана, 2005. - 488 c.

10. Теория ракетных двигателей / В.Е. Алемасов [и др.]. - М.: Машиностроение, 1980. - 533 с.

11. Расчетные исследования внутрикамерного процесса при утилизации нефтяного газа / О.А. Бетинская, Н.Л. Бачев, О.О. Матюнин, Р.В. Бульбович, Н.Ю. Бачева // Нефтяное хозяйство. - 2017. - №7. C. 86-89.

12. Сударев А.В., Антоновский В.И. Камеры сгорания газотурбинных установок. Теплообмен. Л.: Машиностроение, 1985. - 272 с.

13. Теплообмен в камере сгорания для утилизации попутного нефтяного газа / О.А. Зуева, Н.Л. Бачев, Р.В. Бульбович, А.М. Клещевников // Вестник Пермского национального исследовательского политехнического университета. Аэрокосмическая техника. - 2013. - № 34. - С. 52-63.

14. Кутателадзе С.С. Основы теории теплообмена. - Новосибирск: Наука, 1970. - 659 с.

15. Андрианов В.Н. Основы радиационного и сложного теплообмена. - М.: Энергия, 1972. - 464 с.

\section{References}

1. Betinskaya O.A. Organizatsiya rabochego protsessa v universalnoy kamere sgoraniya gazoturbinnoy ustanovki dlya utilizatsii poputnogo neftyanogo gaza [Organization of the working process in the universal combustion chamber of a gas turbine unit for utilization of associated petroleum gas. Abstract of Ph. D. thesis. Perm, 2017,146 p.

2. Betinskaya O.A. (Zuyeva O.A.), Bachev N.L., Bulbovich R.V., Kleshchevnikov A.M. Vybor geometricheskikh, rezhimnykh i teplovykh parametrov vysokoresursnoy kamery sgoraniya dlya utilizatsii PNG [The choice of geometric, regime and thermal parameters of a high-resource combustion chamber for utilization of associated petroleum gas]. Gazovaya promyshlennost, 2013, no. 698, pp. 94-97.

3. Betinskaya O.A. (Zuyeva O.A.), Bachev N.L., Bulbovich R.V., Kleshchevnikov A.M. Vybor geometricheskikh, rezhimnykh i teplovykh parametrov vysokoresursnoy kamery sgoraniya dlya utilizatsii poputnogo neftyanogo gaza [The choice of geometric, regime and thermal parameters of a high-resource combustion chamber for utilization of associated petroleum gas]. Bulletin of the Perm National Research Polytechnic University. Aerospace Engineering, Perm, 2013, no. 34, pp. 40-51. 
4. Shilova A.A. (Selivanova A.A.), Bachev N.L., Bulbovich R.V., Matyunin O.O. Analiz parametrov naruzhnogo protivotochnogo okhlazhdeniya kamery sgoraniya $\mathrm{V}$ sostave utilizatsionnoy energoustanovki [Analysis of the parameters of the external countercurrent cooling of the combustion chamber in the composition of the utilization power plant] Bulletin of the Perm National Research Polytechnic University. Aerospace Engineering, Perm, 2017, no. 50, pp. 80-89.

5. Betinskaya O.A. (Zuyeva O.A.). Kontsentratsionnyye predely goreniya poputnykh neftyanykh gazov [Concentration limits of combustion of associated petroleum gases]. Bulletin of the Perm National Research Polytechnic University. Aerospace Engineering, Perm, 2014, no. 37, pp. 140-153.

6. Betinskaya O.A. Predely ustoychivogo goreniya neftyanykh gazov [Limits of sustained combustion of petroleum gases]. Neftyanoye khozyaystvo, 2014, no. 1089, pp. 64-66.

7. Inozemtsev A.A., Nikhamkin M.A., Sandratskiy V.L. Osnovy konstruirovaniya aviatsionnykh dvigateley i energeticheskikh ustanovok [Basics of designing aircraft engines and power plants]. Moscow: Metallurgiya, 2008, vol. 2, pp. 368.

8. Matyunin O.O, Bachev N.L., Bul'bovich R.V., Bacheva N.YU. Ispolzovaniye antikorrozionnykh prisadok pri szhiganii serosoderzhashchikh uglevodorodnykh topliv [The use of anticorrosive additives in the combustion of sulfur-containing hydrocarbon fuels]. Bulletin of the Perm National Research Polytechnic University. Aerospace Engineering, Perm, 2017, no. 49, pp. 78-88.

9. Dobrovolskiy M.V. Zhidkostnyye raketnyye dvigateli [Liquid rocket engines]. Moscow: Bauman Moscow State Technical University, 2005, 488 p.

10. Alemasov V.Ye. Teoriya raketnykh dvigateley [Theory of rocket engines]. Moscow: Mashinostroyeniye, 1980, $533 \mathrm{p}$.

11. Betinskaya O.A., Bachev N.L., Matyunin O.O, Bul'bovich R.V., Bacheva N.YU. Raschetnyye issledovaniya vnutrikamernogo protsessa pri utilizatsii neftyanogo gaza [Calculation studies of the intra-chamber process in the utilization of petroleum gas]. Neftyanoye khozyaystvo, 2017, no. 7, pp. 86-89.

12. Sudarev A.V., Antonovskiy V.I. Kamery sgoraniya gazoturbinnykh ustanovok. Teploobmen. [Combustion chambers of gas turbine installations. Heat exchange]. Leningrad: Mashinostroyeniye, 1985, 272 p.

13. Betinskaya O.A. (Zuyeva O.A.), Bachev N.L., Bulbovich R.V., Kleshchevnikov A.M. Teploobmen v kamere sgoraniya dlya utilizatsii poputnogo neftyanogo [Heat exchange in the combustion chamber for the utilization of associated petroleum gas]. Bulletin of the Perm National Research Polytechnic University. Aerospace Engineering, Perm, 2013, no. 34, pp. 52-63.

14. Kutateladze S.S. Osnovy teorii teploobmena [Fundamentals of the theory of heat transfer]. Novosibirsk: Nauka, 1970, 659 p.

15. Andrianov V.N. Osnovy radiatsionnogo i slozhnogo teploobmena [Fundamentals of radiation and complex heat transfer]. Moscow: Energiya, 1972, 464 p.

\section{Об авторах}

Матюнин Олег Олегович (Пермь, Россия) - старший преподаватель кафедры «Ракетнокосмическая техника и энергетические системы» Пермского национального исследовательского политехнического университета (614990, г. Пермь, Комсомольский пр., д. 29), e-mail: matoleg@gmail.com.

Шилова Алена Алексеевна (Пермь, Россия) - студентка кафедры «Ракетно-космическая техника и энергетические системы» Пермского национального исследовательского политехнического университета (614990, г. Пермь, Комсомольский пр., д. 29), e-mail: alyona1203@gmail.com.

Бачев Николай Леонидович (Пермь, Россия) - кандидат технических наук, профессор кафедры «Ракетно-космическая техника и энергетические системы» Пермского национального исследовательского политехнического университета (614990, г. Пермь, Комсомольский пр., д. 29), e-mail: bn154@yandex.ru.

Бульбович Роман Васильевич (Пермь, Россия) - доктор технических наук, профессор кафедры «Ракетно-космическая техника и энергетические системы» Пермского национального исследовательского политехнического университета (614990, г. Пермь, Комсомольский пр., д. 29), e-mail: dekan_akf@pstu.ru. 


\begin{abstract}
About the authors
Oleg O. Matyunin (Perm, Russian Federation) - Senior Lecturer, Department of Rocket and Space Engineering and Power Generating Systems, Perm National Research Polytechnic University (29, Komsomolsky av., Perm, 614990, Russian Federation, e-mail: matoleg@ gmail.com).

Alyona A. Shilova (Perm, Russian Federation) - Student, Department of Rocket and Space Engineering and Power Generating Systems, Perm National Research Polytechnic University (29, Komsomolsky av., Perm, 614990, Russian Federation, e-mail: alyona1203@gmail.com).

Nikolay L. Bachev (Perm, Russian Federation) - Ph. D. in Technical Sciences, Professor, Department of Rocket and Space Engineering and Power Generating Systems, Perm National Research Polytechnic University (29, Komsomolsky av., Perm, 614990, Russian Federation, e-mail: bnl54@yandex.ru).

Roman V. Bulbovich (Perm, Russian Federation) - Doctor of Technical Sciences, Professor, Department of Rocket and Space Engineering and Power Generating Systems, Perm National Research Polytechnic University (29, Komsomolsky av., Perm, 614990, Russian Federation, e-mail: dekan_akf@pstu.ru).
\end{abstract}

Получено 01.02.2017 